\title{
Linking Project-Based Interdisciplinary Learning And Recommended Professional Competencies With Business Management, Digital Media, Distance Learning, \\ Engineering Technology, And English \\ Miles Fulwider, Utah Valley University \\ Michael J. Stemkoski, Utah Valley University
}

\begin{abstract}
This paper encourages the investigation of real world problems by students and faculty and links recommended student competencies with project based learning. In addition to the traditional course objectives, project-based learning $(P B L)$ uses real world problems for classroom instruction and fieldwork to connect students, instructors, and industry mentors from several disciplines with the recommended professional competencies required of students entering a profession or career. The purpose and focus of this paper is to inform and enlighten, to instruct and educate, and to evoke industry and community interest by combining educational service value with an educational enterprising activity. The paper demonstrates how project-based learning objectives in the classroom integrate with industry recommended professional competencies in solving real world problems. Utilizing the extraordinary intellectual capital of students and faculty in a learning environment on college campuses allows projects to be arranged and managed in a manner that may also provide funding and grant opportunities. Project-based learning linked to recommended professional competencies is a contributing educational force that addresses the needs in communities, student life, and career choices.
\end{abstract}

Keywords: Teaching Methods and Styles; Business Education; Interdisciplinary Learning and Projects; Project-based Learning.

\section{INTRODUCTION}

n project-based learning (PBL), students, instructors, and mentors work together to develop a finished product or service by combining the topics taught in their courses with applied real world problem solving. This paper is based on the premise that increased student mobility, improved technology, and advances of the Internet are a few of the factors that permit efficient implementation and "new" delivery of projectbased learning. PBL allows for significant creative educational perspectives beyond the traditional classroom. This paper discusses project-based learning practices, processes, and the student competencies that are necessary to be achieved in conducting a comprehensive interdisciplinary learning project. In the past, PBL was difficult to employ. As computer bandwidth increased and technology was enhanced over the Internet, there were fewer constraints in delivering project-based learning. Because of the availability of technology and the mobility of instructors, artists, and mentors, students at Utah Valley University selected live concert productions and documentaries with a socially significant theme as their real world applied projects. The live concert projects and documentaries enhanced the students' capabilities and experiences because the students produced real world products and services complete with licensing and an authored CD and DVD (Begay, Bender, Stemkoski, Raines, \& Walker, 2006). The idea for the 
projects was based on a statement by singer/songwriter and artist Tricia Walker, "Any artist or creative thinker has a responsibility to help chronicle his or her own time, place and people. That's the surest way to keep a culture from disappearing" (Walker, 2006).

\section{LINKING RECOMMENDED PROFESSIONAL COMPETENCIES}

To implement project-based learning, the authors selected three classifications from the accounting profession as their model for recommended competencies that allow for significant educational perspectives, added efficiency, and creativity for interdisciplinary applied learning beyond the classroom. These recommended professional industry competencies are introduced to the students in addition to traditional course objectives. The competencies are easily integrated into a student's educational experience. The recommended competencies by category are listed below. These recommended competencies combined with a real world project are important in helping students to make life decisions, to develop their career or profession, to become work ready, and to enable them to become active members of their community.

1. Functional competencies: Relates to the technical competencies, which are most closely aligned with the value contributed by a student's career or profession. These functional competencies align with the traditional course objectives for each course (AICPA, 2002).

2. Personal competencies: Relates to the attitudes and behaviors of individuals preparing to enter a career or profession. Developing these personal competencies enhances the way relationships are handled in a student's career, and facilitates individual learning and personal improvement in making life choices and in solving problems (AICPA, 2002).

3. Broad business perspective competencies: Relates to the context in which students will perform services and make decisions in their career or profession. Individuals preparing to enter a career should consider both the internal and external discipline specific environments and how their interactions with others determine success or failure. Additionally, the individuals must be familiar with the overall realities and peculiarities in the context of their profession (AICPA, 2002; Autodesk Foundation, 2006; Portland, MA, Public Schools, 2006).

\section{DESCRIPTIONS OF RECOMMENDED COMPETENCIES}

\section{Functional Competencies}

- Decision Modeling: When students work together to produce a finished product or service in the classroom, they tend to objectively consider issues, identify alternatives, and implement solution approaches to deliver the finished product or service. However, students often model previous behavior in their life; and this may influence management styles, learning, and decision making. Students using project-based learning may convey various learned or modeled management behavior. The students, instructors, and mentors will often exhibit decision making styles that are revealed in real world projects. These styles are not easily identifiable in the traditional classroom structure. Additionally, the students, instructors, and mentors may bring previously learned management styles to a project that are observable in each other throughout the decision making process. They learn how to assess the need for sensible trust in each other while working together to solve problems (AICPA, 2002; Rensselaer Polytechnic Institute, 2006). For example, students become aware of ideas outside the textbook and understand the need for community service. Bill Gates, former chairman and founder of Microsoft suggests, "As a father, I believe that the death of a child in Africa is no less poignant or tragic than the death of a child anywhere else. And that it doesn't take much to make an immense difference in these children's lives. I'm still very much an optimist, and I believe that progress on even the world's toughest problems is possible - and it is happening every day. And I believe that through our natural inventiveness, creativity and willingness to solve problems, we're going to make some amazing achievements in all areas in my lifetime" (Gates, 2005). With the intellectual capital and technology available among students and faculty on campuses around the country and in the world, PBL opens new possibilities.

- $\quad$ Risk Analysis: Risk analysis and control is fundamental to service delivery and project development. Project-based learning exposes students to the need for identifying, defining, and managing risk. They are exposed 
to situations that detect misstatements caused by inadvertent errors, posturing, overstatement and understatement of material facts in both oral and written statements. The students begin to understand how risk assessment in project management shapes the implementation of business strategies. Students learn to keep work activities in prospective and assess risk by "doing the real thing." Risk assessment is vital for making life choices and in making decisions (AICPA, 2002). For instance, the "Barefoot" workshops are examples of multimedia educational experiences that combine real world project-based learning with student hands-on projects. Education is being advanced in a workshop format rather than by merely a lecture. The real world film projects join students with personnel from industry and generate corporate alliances to teach students writing, storytelling, and documentary filmmaking. The instruction setting is in the Mississippi Delta. "At the end of the barefoot experience, students should walk away with technical know-how and confidence, the proper industry work code, the ability to tell a story, a new appreciation and way of looking at people, and most importantly a new way of looking at themselves. At Barefoot, growing and learning as a filmmaker means growing and learning as an individual" (Barefoot Trailer, 2006; Barefoot Workshops, 2006, para. 1).

- Measurement: Reports measuring results and performance should be relevant, reliable, verifiable, valid, timely, understandable, consistent, and comparable. Reports assess the performance and results of the project and provide feedback regarding the decisions made, and the standards and objectives being achieved or not achieved. Students are made aware that there are different measurement metrics, gauges, or standards in managing a project that are similar to dashboard gauges in an automobile that give feedback on the critical aspects of the operations. Also, the performance measures in project-based learning expose the students to criteria and metrics (measurements) to compare costs. In the live Utah Valley University concert and documentary projects, students compared and differentiated costs of hotels, printing, airline tickets, theater and automobile rentals, meals, ticket prices, and product sale prices. The students needed to considered Web site design costs and other expenses necessary in meeting or exceeding the objectives of the project. Exposing students to measurements and reporting of results also serves to generate budget activities that parallel personal financial decisions such as house buying, mortgage assessment, and automobile purchase decisions (AICPA, 2002). The knowledge, experience, and awareness of developing and managing projects are transferable to a student's personal finance and life decisions.

- $\quad$ Reporting: Clearly and objectively communicating the results, findings, and work done is critical to assessing the results of a real world project. Some forms of communication are governed by professional standards or law. Others are based on the service applied and the needs of those to whom the person responsible reports. Communicating the scope of work required, findings, and recommendations is an integral part of professional service and project-based learning applications (AICPA, 2002). For example, the students involved in the concert projects and documentary project were required to research copyright and download licensing requirements, along with rights involving intellectual property for songs used in the live concerts and the documentary.

- $\quad$ Research: Although professions need standards and other relevant rules, such guidance is constantly evolving. Many professional functions depend on obtaining information from within and outside of an entity or company. Understanding the metric or metrics that measure a particular project, business, or economy is necessary to gain insight into various companies, industries, and project peculiarities (Cramer, 2005, p. 81). Accordingly, individuals preparing to enter a career gain knowledge using project-based learning for marketing research and other disciplines. Students learn to integrate their research among disciplines. For example, Utah Valley University English classes that participated in the concert projects analyzed songs by the singer songwriters that contained lyrics regarding human rights issues. In another instance, songs were written about historical events such as the Civil War. Students learned research skills and sought relevant individual guidance from the songwriters that applied to their writing assignments, decision making, and analysis (AICPA, 2002). This research gave the students the opportunity to produce a concert with a story. They worked with professionally accomplished and award winning composers and songwriters.

- Leverage Technology to Develop and Enhance Functional Competencies: Technology is inclusive in all professions. Individuals entering a career must acquire the necessary skills to use technology tools effectively and efficiently. Whether a student is in accounting, business management, finance, human resource management, digital media, graphic design, distance education, engineering or English, students need to learn and become aware of the 
technology and software specific to their profession or discipline (AICPA, 2002). This technological association with other students and disciplines creates an atmosphere for cross functional learning possibilities and innovative teaching processes.

\section{Personal Competencies}

- Problem Solving and Decision Making: This competency involves demonstrating self-confidence, goal setting, positive attitude, focus, objectivity, patience, respect, conflict resolution, integrity, and ethical behavior. It also includes a commitment to stable work performance, as well as being committed to continuously acquiring new skills and knowledge in achieving or exceeding standards of performance to attain results. Career-minded individuals and professionals are often asked to distinguish the true nature of a situation, and then determine the principles and techniques needed to solve problems or make judgments. Thus, individuals entering a profession should display effective problem solving and decision-making skills, quality insight and judgment, and innovative creative thinking (AICPA, 2002). For example, the students producing a live concert project or documentary were required to review and correct problems from Friday night's concert before the Saturday evening show. Two shows were completed to give the students the time to evaluate their work and take corrective action with counter measures. This required students to devote all day Saturday to reviewing their work with diagnosing cause and effects of errors or failures in the first show. The students are also presented with The Toyota Way Fieldbook. For example, one of the principles states that individuals need to be responsible, strive to decide their own fate, and act with self-reliance and trust their abilities. Another principle states that individuals need to accept responsibility for their conduct and maintain and improve the skills that enable them to produce added value. An additional principle states that after an individual completes a project, he or she should openly identify all the shortcomings of the project and develop countermeasures to avoid the same mistakes again (Liker \& Meier, 2006, p. 354-355).

- Interaction: Students, instructors, and mentors must be able to work with other professionals to accomplish objectives. This requires them to act as valuable partners within organizations and markets, and to work together to provide solutions to problems (AICPA, 2002). Individuals need to respect extended networks of partners and suppliers by challenging them and helping them improve (Liker \& Meier, 2006, p. 303-304).

- $\quad$ Leadership: Individuals entering a profession and making life decisions should be able to effectively lead in various circumstances and assist others when needed. This does not mean doing the work for another, but aiding the individual. Leaders might need to learn how to ask relevant and important questions and learn how to give support. The leader may also need to become skilled in empowering the individual to make the decision. This involves acquiring the skills needed to delegate, influence, inspire, and motivate individuals, along with understanding the need for follow-up and verification of results. The ethical considerations of leadership are also recognized in individuals when completing real world projects (AICPA, 2002). Individuals should not view the leader's job as simply accomplishing tasks and having good people skills. Leaders must be role models of the company's philosophy and way of doing business and be able to select the right people for the job (Liker \& Meier, 2006, p. 240-241). Students found selecting the right people to be difficult.

- Communication: Individuals entering a profession or making life choices need to communicate information so that it is understood by individuals who have diverse capabilities and interests. For example, individuals entering a profession should have the skills necessary to provide and exchange information within a meaningful context and with appropriate delivery. They should have the ability to listen, deliver powerful presentations, and produce examples of effective writing. Each discipline has its own industrial peculiarities for making decisions (AICPA, 2002). Real world interdisciplinary projects facilitate an opportunity for the students by positioning them to work together as a team. The projects are comprehensive with students depending on each other for the project's success.

- $\quad$ Project Management: Individuals entering a profession or making life choices must successfully manage a diverse range of personal projects throughout their career and life. Individuals should demonstrate the ability to effectively control the course of multi-dimensional and multi-step undertakings. These include managing project 
assets, human capital (talent), financial and non-financial information, property assets and technology driven resources (AICPA, 2002).

- Leverage Technology to Develop and Enhance Personal Competencies: Technological adaptability is a requirement for today's professionals. As technology advances, individuals must acquire new skills and determine how new technologies should be incorporated into their profession and life. Finally, integrating and exposing students to continuous technological learning among disciplines enhances the development, understanding, and application of the related competencies including decision making, human relations, and communication skills (AICPA, 2002).

\section{Broad Business Perspective Competencies}

- Strategic/Critical Thinking: Critical thinking encompasses the ability to link data, knowledge, and insight to different disciplines while providing information to make decisions and solve problems. Being in tune with the "big picture" perspective is necessary to help compare a decision's cause and effect on other disciplines. The cause and effect needs to be analyzed with sufficient validation to strive to understand any repercussions a decision may have on other phases of the project, individuals, and departments. Individuals should be given an educational opportunity to practice communicating to others the vision, strategy, goals, and objectives of their decision and to apply what they learn to a real world situation.

- Implementation and Execution: One way to reduce oversight in decision making is to require students, instructors, and mentors to articulate to each other and to a knowledgeable, experienced, independent person (sounding board). They communicate the purpose and reasoning for the project decision and how the strategy and tactic will meet or exceed a particular project objective. For example, Karen Cramer ("Trading Goddess" and successful stock trader on Wall Street) often asked her husband James Cramer (a successful money and hedge fund manager on Wall Street, for a number of years) the following sample questions, over and over again, to have him explain his decisions and stock picks. The below questions in italics are adapted from Cramer's sample stock pick questions for project-based learning (Cramer, 2005, pp. 177-178):

1. What's going to make this stock go up? (What will make this project improve, succeed, and be profitable?)

2. Why is it going to go up when you think it is? (Why and how will the project improvement decision enhance and add value to the project? What is the time frame?)

3. Is this really the best time to buy? (Is this the best time to implement the project decision?)

4. Haven't we already missed a lot of the move? (Is it too late, and/or is there a need to correct the decision?)

5. Shouldn't we wait until it comes down a little more? (Should the decision be implemented or delayed?)

6. What do you know about this stock that others don't know? (What is known about this project and the decision that others do not know?)

7. What's your edge? (What is the edge in this project or decision?)

8. Do you like this stock any more than any of the others you own and why? (Is this project, decision, or improvement favored over other alternatives and why?)

The last question is important because it suggests that it is impossible to have dozens of good ideas at once where a person could have an edge (Cramer, 2005, p. 178). Without a sounding board, it is not possible to be rigorous enough or have enough discipline and conviction in a decision. With the use of the Internet, making decisions can be a solitary event (Cramer, 2005, p. 177). The above example of buying stock or managing a project is similar to buying a house or buying or leasing an automobile. One decision may have repercussions, transfer costs, or opportunity costs when compared to other alternatives. Project-based learning creates the motivation among students, instructors, and mentors to do homework, reading, research, and to prepare for an important decision that is being considered. This type of learning process is self-directed and continuous. It encourages doing a lot of homework and research when making decisions while using a trustworthy capable person(s) as a sounding board(s) (AICPA, 2002; Cramer, 2005, p.178). Students engaged in project-based learning generally work in cooperative groups. They solve problems, generating a performance assessment of the outcomes that are based on the process of the work performed and products and services produced (Ahalt, 2005). Mark Ahalt (2003) who was a 
teacher on Special Assignment at the District Office and Coordinator and is a Riverside Project Teacher at Mazama High School in Klamath Falls, Oregon asked, "How can we expect young people to achieve financially if they can't understand the stock market, don't know how interest rates work, or even how to manage their credit cards" (p. 8). Project-based learning places the student at the center of the learning process and in an environment where they need to be responsible for their actions, successes, and mistakes.

- Industry/Sector Perspective: Individuals entering a profession and making life choices should identify through research and analysis the economics and broad business financial risks of their decisions. In addition, students need to become aware of opportunities in the industry and economic sector in which a given individual or organization operates. For example, English students may become more aware of the publishing business and its industrial peculiarities when selecting a writing career. Identification of these risks and opportunities should include both issues specific to the enterprise, as well as those pervasive and peculiar throughout the industry, sector, and discipline (AICPA, 2002). As Cramer (2005) states, "There's a terrible desire among professionals and amateurs not to try something new, not look at new markets or new stocks. The aversion comes from the amount of work that is required to learn new groups and from the belief that you can't stretch your knowledge" (p. 179). It is a risk and experiment to engage students in a real world project. Georgia Institute of Technology assists The International Community School by attracting students and faculty from Emory University, Georgia State University, and the Atlanta International School. International students and international affairs majors from Georgia Institute of Technology assist the school's staff and work with the children at the International Community School (Georgia Institute of Technology, 2006). Mohamed Kone, a student volunteer from the Ivory Coast, stated, "I don't feel right when I'm not volunteering" (Georgia Institute of Technology, 2006, para. 10).

- International/Global Perspective: Individuals entering a profession should identify and communicate the variety of opportunities and threats of doing business in a borderless world. The professional of the future must provide services to support and facilitate commerce in the global marketplace and in emerging economies (AICPA, 2002).

- Resource Management: The ability to appreciate the importance of all resources (human, financial, physical, technological, and environmental) is critical for success in analyzing future decisions. Individuals entering a profession and making life choices should apply management and human development information to human issues and organizational problems. Furthermore, individuals preparing to enter a profession and making decisions in life may need to understand the accumulation of future sums of money, compound interest, the future sum of equal periodic payments for investments at a reasonable rate of return, or calculate interest rate alternatives for purchases while identifying different sources of capital (Moneychimp, 2006; TIB Bank, 2006). An individual should analyze and become aware of the accountability and the measurements necessary to evaluate local and global community services (AICPA, 2002). This may lead to a better understanding of how to evaluate the effectiveness of schools, police departments, fire protection, water supplies, and other environmental, social, and governmental services. For example, the philanthropic arm of AT\&T Inc. (NYSE: T) and NCCEP announced a \$50,000 grant for Oregon GEAR UP. This is an educational partnership with Oregon Institute of Technology to provide a four-week residential academic program to rising $10^{\text {th }}$ and $11^{\text {th }}$ graders at Chiloquin Junior and Senior High School" (NCCEP, 2006, pg. 3). The Chiloquin students benefit greatly from this experiential educational opportunity with the Global Positioning System (GPS) units. About $72 \%$ of these students are economically disadvantaged (NCCEP, 2006, pg. 3). This project-based learning experience gives students exposure to future scholarship opportunities. "According to the Department of Education study, high academic achievers from low-income families are only one-fifth as likely to enroll in college as similar students from high-income families" (NCCEP, 2006; U.S. Department of Education, 2006, para. 5).

- Legal/Regulatory Perspective: Regulatory forces are being created by collaboration, change, and reform as the various stakeholders globalize, share information, and push their particular needs and viewpoints onto political agendas. Individuals need to describe and assess the legal and regulatory environment and analyze the impact of changes. For example, an individual may need to make many decisions such as lease or purchase decisions for automobiles, equipment, and asset acquisitions that include tax law considerations, licensing decisions, mortgage decisions, credit card purchases and payments, cell phone decisions, and retirement comparisons. 
Moreover, individuals need to know how to acquire enough knowledge and information about a decision or purchase to be a "good client" or "knowledgeable" customer (AICPA, 2002; Cramer, 2005; Hagstrom, 2001). If a student does not have enough information, experience, or knowledge to make an informed decision, then the student needs to acquire the methods and processes to become an informed and knowledgeable client. The students become capable of creating a project and being excellent managers while experiencing what it means to become a "good client" and a "good customer." The projects also emphasize that the student is responsible for his or her performance and results (Cramer, 2005 p. 10).

- Marketing/Focus: Individuals who are marketing focused and oriented to serving others usually improve on meeting the changing needs of clients, employers, customers, and other stakeholders in the market place. This involves both the ability to recognize market and sales needs along with the capacity to develop new markets (AICPA, 2002). The concert and documentary projects provided an excellent learning dynamic due to the transitions occurring in the digital world with downloads and other aspects of the record and entertainment industry. The industry is desperately trying to experiment with various business models. This change in the industry created an opportunity for students to research a range of business models.

- Leverage Technology to Develop and Enhance a Broad Business Perspective: Technology alters how organizations and individuals within a discipline operate. To provide and create value, today's professional must understand and appreciate the effects of technology on the broader interdisciplinary environment. Whether a student is majoring in the arts, music, dance, graphic design, engineering, or English, there is a business, accounting, finance, tax, law, and technology aspect to each discipline (AICPA, 2002). The late media theorist Marshall McLuhan believed the senses become extended outside of an individual's body. He suggested that a book was an extension of the eye, and a car was an extension of the foot. McLuhan would say the Internet is an extension of the central nervous systems. Project-based learning (PBL) is also an extension from the classroom to an applied realworld learning atmosphere and is integrated with the Internet to permit students to gain and transfer information (Boese, 2004).

\section{CONCLUSION}

This paper demonstrates the need for students and instructors to consider recommended professional competencies linked with project-based learning to strengthen decision making. The strong point of Project-based learning (PBL) is not measured by student performance on multiple-choice exams, but by demonstration of higherorder learning through guided authentic learning activities (Cheaney \& Ingebritsen, 2005). The PBL projects presented in this paper were conducted with anticipation of moving the learning process from disconnected "educational silos on campus" to a learning alliance among disciplines with students, instructors, and industry mentors in solving real world problems. The learning process links the recommended professional competencies to project-based learning.

If students want to experience what it is like to write, then they must write. Writing is doing the real thing. There are benefits to be gained by experiencing the real thing or by conducting a real activity. As Warren Buffet, one of the most capable managers in the world states, "Can you really explain to a fish what it is like to walk on land? One day on land is worth a thousand years of talking about it, and one day running a business has exactly the same kind of value" (as cited in Hagstrom, 2001, p. 5). The direct experience offers many insights that can only be learned from doing the real thing. This is what project-based learning connected to the professional competencies works to accomplish. Finally, "Learning from the best is a dyadic process: it is both a privilege and a responsibility. We gratefully accept wisdom from those who have gone before us; it is our privilege. Then with respect, we pass it on to those who follow; that is our responsibility" (Hagstrom, 2001 p. 252). With innovative processes and experimentation, learning takes place jointly with the students and instructors.

\section{REFERENCES}

1. Ahalt, M. (2003). Unique tools for educators. Cascade update. Cascade Policy Institute, Portland, OR, 10, 8. Retrieved August, 29, 2006, from http://www.cascadepolicy.org/pdf/pub/newsletter4_03.pdf 
2. Ahalt, M. (2005). Model high school. Klamath Falls City Schools strategic planning, Klamath Falls, OR. Retrieved September 1, 2006, from http://www.kfalls.k12.or.us/news/strategic_planning_feb_05_files/strategic_planning_feb_05_files/frame.h tm\#slide0006.htm

3. American Institute of Certified Public Accountants. (2002). AICPA core competency framework for entry into the accounting profession. Retrieved February 4, 2006, from http://www.aicpa.org/edu/corecomp.htm

4. Autodesk Foundation. (2006). Initiatives. Retrieved January 10, 2006, from http://usa.autodesk.com/adsk/servlet/index?siteID=123112\&id=1911339

5. Begay, T., Bender, M., Stemkoski, M., Raines D. \& Walker, T. (Fall 2006). Interdisciplinary project-based learning: an experiment to create real world products and services with clients involving the disciplines of business management, multimedia, distance learning, engineering technology, and English. The Journal of Learning in Higher Education, 2(2), 15-20. Retrieved April 30, 2007, from http://jwpress.com/JLHE/Issues/JLHE-V2I2webversion.pdf?Submit3=Fall+2006+Issue+\%28Copyright+2006+JW+Press\%29

6. Barefoot Trailer. (2006). Barefoot in the Mississippi Delta. Retrieved September 5, 2006, from http://homepage.mac.com/damienblaylock1/barefoottrailer/iMovieTheater7.html

7. Barefoot Workshops. (2006). Retrieved September 5, 2006, from http://www.barefootworkshops.com

8. Boese, C. (2004). The screen-age: our brains in our laptops. CNN.com. Retrieved April 23, 2006, from http://www.cnn.com/2004/TECH/01/26/hln.hot.buzz.silicon.brain/index.html

9. Cheaney, J. \& Ingebritsen, T.S. (2005). Problem-based learning in an online course: a case study. International Review of Research in Open and Distance Learning, 1492-3831. Retrieved January 10, 2006, from http://www.irrodl.org/content/v6.3/cheaney-ingebritsen.html

10. Cramer, J. (2005). Real money: sane investing in an insane world. New York: Simon \& Schuster.

11. Esch, C. (2000). Project-based and problem-based: the same or different? Challenge 2000 multimedia project. San Mateo County Office of Education. San Mateo, CA. Retrieved February 2, 2006, from http://pblmm.k12.ca.us/PBLGuide/PBL\&PBL.htm

12. Gates, B. (2005). Unleashing the power of creativity. NPR, This I believe Retrieved October 9, 2006, from http://www.npr.org/templates/story/story.php?storyId=4853839

13. Georgia Institute of Technology. (2006). University volunteers stimulate international public school. Retrieved September 1, 2006, from http://www.gatech.edu/news-room/release.php?id=234

14. Hagstrom, R. (2001). The essential Buffet: Timeless principles for the new economy. New York: Wiley \& Sons, Inc.

15. Liker, J., \& Meier, D. (2006). The Toyota way fieldbook. New York: McGraw-Hill. (text and internet site).

16. Liker, J., \& Meier, D. (2003). The 14 principles of the Toyota way. Retrieved November 12, 2007, from http://www.si.umich.edu/ICOS/Liker04.pdf

17. Moneychimp. (2006). Compound interest (future value). Retrieved September 1, 2006, from http://www.moneychimp.com/articles/finworks/fmfutval.htm

18. National Council for Community and Education Partnerships. (2006). Oregon Gear Up. Retrieved January 1, 2006. http://www.edpartnerships.org/Content/NavigationMenu/Programs and Services/Programs_Sub_Item/AT andT Grants in Education/2006 ATandT Grants in Education/OREGON AT\&T 2006_Grantees.pdf

19. Portland, MA, Public Schools. (2006). What is project based learning? Retrieved January 15, 2006, from http://moore.portlandschools.org/ibook/documents/What\%20is\%20PBL.pdf

20. Rensselaer Polytechnic Institute. (2006). Management styles. Retrieved September 1, 2006, from http://www.rpi.edu/dept/advising/free enterprise/business_structures/management_styles.htm

21. TIB Bank (2006). Financial tools. Retrieved September 2, 2006, from http://www.tibbank.com/ft_value_annuity.html

22. U. S. Department of Education. (2006). Retrieved September 14, 2006, from http://www.ed.gov/index.jhtml

23. Walker, T. (2006). Retrieved December 11, 2006, from www.bigfrontporch.com/tricia/index.html 